\title{
Geodiversity and geoheritage: Detecting scientific and geographic biases and gaps through a bibliometric study
}

\author{
Juan-José Ibáñez ${ }^{\mathrm{a}}$, Eric C. Brevik ${ }^{\mathrm{b}, *}$, Artemi Cerdà ${ }^{\mathrm{c}}$ \\ ${ }^{a}$ National Museum of Natural History of Spain (MNCN), Spanish National Research Council (CSIC), Serrano 115 dpdo, 28006 Madrid, Spain \\ b Department of Natural Sciences, Dickinson State University, Dickinson, ND 58601, USA \\ c Soil Erosion and Degradation Research Group, Departament de Geografia, Universitat de València, Blasco Ibáñez 28, Valencia, Spain
}

\section{H I G H L I G H T S}

- Geodiversity and pedodiversity should receive as much attention as biodiversity.

- Pedodiversity is part of geodiversity but rarely considered in geodiversity studies.

- Pedodiversity studies followed biodiversity methodologies, geodiversity did not.

- Geodiversity has focused on the proposal of geoparks, geotourism, and education.

- Researching relationships between bio-, pedo- and geodiversity would be fruitful.

\section{A R T I C L E I N F O}

\section{Article history:}

Received 11 March 2018

Received in revised form 30 August 2018

Accepted 28 December 2018

Available online 29 December 2018

\section{Keywords:}

Geodiversity

Pedodiversity

Biodiversity

Geoheritage

Geoparks

Scopus

Google Scholar
G R A P H I C A L A B S T R A C T

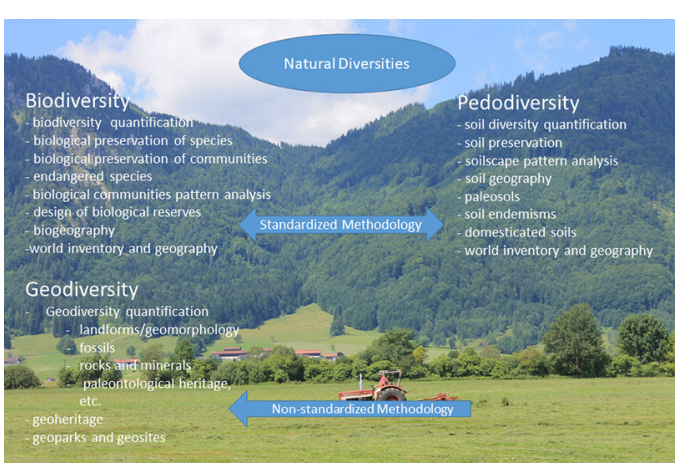

\begin{abstract}
A B S T R A C T
Many scientists have recognized that there is diversity in nature, including biodiversity, geodiversity, and pedodiversity. Studies in biodiversity date back as far as the 1700s, but geodiversity and pedodiversity studies are much more recent, dating to the late 1970s to early 1980s. Given that we are now approaching 40 years of geodiversity and geoheritage work, this study was undertaken to determine areas that have been well addressed and where current gaps are. This was accomplished by reviewing the publications in the journal "Geoheritage", the Scopus and Google Scholar databases, and established geoparks according to UNESCO records. It was found that geodiversity studies typically do not include the findings or utilize the techniques of biodiversity and pedodiversity research, despite the fact that common definitions of geodiversity include soils. Including the findings and techniques of bio- and pedodiversity would expand geodiversity work. Likewise, geoheritage preservation sites are not geographically balanced, with European countries, Brazil, Australia, and China creating the large majority. The European and East Asian countries, especially China, have dominated in the establishment of geoparks. The most pressing need in future studies is more balanced geographic distribution, as the current strong slant towards a limited portion of the world cannot adequately capture (on the research front) and preserve (on the geoparks front) global geodiversity. Finally, there is a need investigate whether the spatial patterns of biodiversity are idiosyncratic or are also a characteristic of abiotic resources, permitting the standardization of diversity research methods. This review contends that there are intriguing similarities in biodiversity, geodiversity, and pedodiversity patterns that should be explored, something that would benefit all of these research areas.
\end{abstract}

(c) 2018 Elsevier B.V. All rights reserved.

\footnotetext{
* Corresponding author.

E-mail address: eric.brevik@dickinsonstate.edu (E.C. Brevik).
} 


\section{Introduction}

Human perception of nature and society is a key issue for the understanding of the interaction of humans and nature (Huxley, 1954), and understanding the interactions between humans and nature is a growing field of study (Pereira et al., 2016; Teshome et al., 2016). These perceptions are relevant as they will affect policies, land management, and as a consequence, the future of landscapes (Tempesta, 2010; Soini et al., 2012). The traditional biophysical approach to nature issues is now completed with societal, economic and perception studies to understand the Earth system from a holistic perspective. For example, this has been documented in agriculture lands were the perception of the use of catch crops and weeds to protect the soil must be designed in a system that includes the opinion of the farmers (e.g. Cerdà et al., 2018).

Humans have recognized that some landscapes are more diverse than others, regardless of observed natural resources. All environmental scientists understand that some areas are richer than others in living organisms, rocks, landforms, soils, or a combination of these. The concept of diversity is clear and intuitive regardless of the studied subject, and terms such as biodiversity, geodiversity, and pedodiversity have been assigned to the study of this concept with a focus on various aspects of the natural system. Many definitions have been proposed for the concepts of biodiversity, geodiversity and biodiversity. However, in the absence of consensus, such proliferation turns out to be more harmful than beneficial. In our opinion, the following definition of diversity by Huston (1994) is applicable to all types of natural resources, so it turns out to be enlightening. According to Huston, diversity can be conceptually defined as: "The concept of diversity has two primary components, and two unavoidable value judgements. The primary components are statistical properties that are common to any mixture of different objects, whether the objects are balls of different colours, segments of DNA that code for different proteins, species or higher taxonomic levels, or soil types or habitat patches on a landscape. Each of these groups of items has two fundamental properties: 1 . the number of different types of objects (e.g., species, soil types) in the mixture or sample; and 2. the relative number or amount of each different type of object. The value judgements are 1. whether the selected classes are different enough to be considered separate types of objects; and 2. whether the objects in a particular class are similar enough to be considered the same type. On these distinctions hangs the quantification of biological diversity" (Huston, 1994, p. 65).

From a scientific point of view the problem is to propose concepts that can be useful in order to determine the diversity of the physical landscape; to achieve sustainable management it is necessary to understand and quantify all landscape diversities, irrespective of whether they are biotic or abiotic. When the former purpose is reached we call this the operationalization of a concept. An operational concept is the first step in the birth and progress of a given discipline (i.e., Steward, 1986; Jacobs et al., 2009). In general the sciences start with qualitative conceptual development that with time gives rise to semi-quantitative and finally quantitative concepts that allow us to compare the objects of study. The operationalization of the concept of diversity has not been an easy task in any of the natural resources disciplines because there are many obstacles that complicate it (Bunnell, 1998; Valls et al., 2015). The first is that nature is complex and multifaceted. For example, biodiversity can be estimated from many points of view such as genetic diversity, taxonomic diversity (e.g. biological species), diversity of ecosystems, or functional diversity (Noss, 1990; Sites and Marshall, 2004). The same occurs within the emergent field of geodiversity.

The current difference between the studies of biodiversity and geodiversity is that the scientific community has studied the first for many decades, while the second interest has emerged more recently. Studies in biodiversity have a relatively long history in terms of trying to understand diversity in natural systems, with some dating the earliest biodiversity studies to the 1700 and 1800s (Harper and Benton, 2001; Huston, 1997; Naeem et al., 2002), while geodiversity and pedodiversity studies are more recent, dating to the late 1970 s to early 1980s (Beckett and Bie, 1978; Karjalainen, 1983). In fact, published pedodiversity research preceded the more general geodiversity research (Ibáñez et al., 1990, 1994, 1995; De-Alba et al., 1993), despite the fact that geodiversity experts will often claim pedodiversity as part of their field.

Given that we are now approaching 40 years of geodiversity and pedodiversity studies, it seems appropriate to conduct an analysis of and detect current gaps in the trends in these studies to quantify their coverage, identify areas with different diversities, to select areas that merit protection. Therefore, the goal of this study was to utilize a datamining of the papers published in the journal "Geoheritage" as well as the Scopus and Google Scholar databases to investigate these trends, including a focus on the place that soils have had in geodiversity studies as well as to what extent geodiversity studies have been able to detect the areas of the earth's surface that must be protected due to the uniqueness of their geological resources in the broadest sense of the term at the worldwide level.

\section{Materials and methods}

All the contents of Geoheritage Journal were analyzed from the first issue in 2009 to November 2016, totaling 187 papers. The number of times that individual countries were mentioned, the country(ies) where the authors of the articles worked, and the number of times selected key terms (as determined by the authors of this paper, not the key words in the strict sense of the terms that appear in the papers) appeared that were considered relevant directly or indirectly in order to understand the frequency of subjects/disciplines addressed were analyzed. Similarly, the papers were carefully classified "ad hoc" in order to provide a general idea of the scientific approaches adopted in each article. UNESCO (2017) data was analyzed to see which countries have been most active in establishing geoparks, as this was seen as being a measure of broader national interest in geodiversity that was somewhat independent of the countries where authors conducting geodiversity studies are located and of the number of times that various countries were included in academic geodiversity studies. Likewise it seems of paramount importance to understand if current geoparks coverage is geographically distributed in such a way that it is able to provide a representative picture of the geodiversity of the planet. Rank abundance plots, the most common form of sorting data in biodiversity and pedodiversity studies (e.g. Magurran, 2004), were used to analyze the subjects addressed in the articles reviewed when such analysis was appropriate. Similarly, the data was tested to see if it fit a linear regression model or a power law model. In diversity analysis the data usually fits a power law better than a lineal distribution. Some key terms give direct information of the main objectives where as others inform of the main focus of the papers. This is an approach to try a type of data metaanalysis to improve understanding of the context of the main key terms to achieve the purposes of this study.

The analysis of papers from a single journal necessarily suffers from biases that cannot be avoided. To help avoid such logical shortcomings a similar approach was used searching terms that are most closely related to the subject of this study using the Google Scholar and Scopus databases beginning in 1980. The Google Scholar database was analyzed on 02 February 2017 and Scopus through 29 November 2016. The results obtained from these two databases were similar. In Google Scholar single terms related to geodiversity, pedodiversity, and geoheritage were searched first and after that the search was refined as first entries and related terms in a second search.

Finally, an "ad hoc" classification of the papers submitted to Geoheritage Journal, according to their main focus, was carried out. The papers were classified as being case studies of local interest, case studies of general interest, papers that sought to develop theoretical or methodological aspects of geodiversity, papers that were educational in nature (focused on the role of geoheritage preservation in the education of students, the public, etc.), thematic papers (those focused on a 
single feature of geodiversity, such as karst, fossils, etc.), reviews, and others (papers that didn't fit any of the other subdivisions, which included editorials). This type of classification has some shortcomings but permits conclusions to be reached concerning to what extent the concepts and their quantification are formalized, as well as whether the global coverage of the items addressed is balanced.

The data was analyzed in several ways. The number of publications and geoparks were summed and the total numbers compared by country and region. Similarly, the number of times that a given key term appeared in the database searches was determined and the most frequently used key terms determined. Common diversity indices (richness - S, Shannon index $-\mathrm{H}$, and equitability - E, as well as the models of distribution of abundance) (Shannon and Weaver, 1949) were applied to the key terms to determine their distributions and equitability. The most common abundance distribution models are the geometric series, the logarithmic series, the logarithmic normal distribution, and the "broken stick" model (Ibáñez et al., 1995). Of these, the geometric series is the least equitable, meaning that a few objects in the classification dominate while all others are very rare. This is followed by the logarithmic series and the logarithmic normal distribution, with the "broken stick" model being the most equitable. While some natural distributions fit other models, the use of these four as often as possible has been recommended as a way to standardize methods and allow comparisons between studies (Ibáñez et al., 1995; Magurran, 2004).

\section{Results and discussion}

\subsection{Publications and geoparks by country using Geoheritage papers and UNESCO geoparks}

The distribution of studies was not equitable by country or continental region (Tables 1-3). The data for author nationality, countries investigated by the research projects, and the establishment of geoparks followed hollow curve distributions (Figs. 1-4), which is the dominant structure found in diversity data (e.g. Ibáñez et al., 1995; Magurran, 2004). However, the results obtained were not equitable as occurs in biodiversity and pedodiversity analyses for natural data. Geodiversity research seems to be concentrated in a few countries that are interested in the analysis of the preservation of geological heritage with rapid decrease in attention from most countries (a typical hollow curve); researchers from many countries have not published a single paper. Researchers in the European countries have shown particular interest in geodiversity work, with seven of the top 10 countries in terms of numbers of authors publishing papers being from Europe (the "several countries" entry in Table 1 being ignored for the purposes of this evaluation). In terms of the number of papers in which a given country was included, the top 17 countries are European. Brazil, China, and Australia are additional countries with researchers who have shown a fairly large interest in geodiversity through their publication records (Tables 1 and 2). The USA Department of State recognizes 195 independent States (US Dept. of State, 2017) while the United Nations has 193 member states (UN, 2018). Authors based in 40 countries (only about $20 \%$ of the world's nations) have authored papers in Geoheritage. Geoheritage is a young journal, but it is notable that geologists in some countries with healthy, vibrant geological communities such as the USA or Russia do not seem to show much interest in sharing and discussing their knowledge and initiatives in this journal/area.

Obviously we should not infer that the experts of countries that publish more papers are more interested than others based only on this data. However, the unequal distribution of studies and researchers should be a matter of concern considering that a scientific discipline's progress benefits from multiple perspectives and viewpoints (Scheffer, 1999). This is something that should be achieved when experts from many countries share information with their colleagues in the international scientific community concerning their respective strategies and methodologies. If each country designs its own strategies without
Table 1

Country of institutional affiliation for authors of papers in Geoheritage Journal.

\begin{tabular}{|c|c|}
\hline Country & Number of papers \\
\hline Italy & 36 \\
\hline Several countries ${ }^{a}$ & 28 \\
\hline Brazil & 15 \\
\hline Spain & 15 \\
\hline Australia & 13 \\
\hline United Kingdom & 12 \\
\hline Portugal & 9 \\
\hline France & 6 \\
\hline China & 4 \\
\hline Poland & 4 \\
\hline Bulgaria & 2 \\
\hline Cameroon & 2 \\
\hline Canada & 2 \\
\hline Czech Republic & 2 \\
\hline Germany & 2 \\
\hline Greece & 2 \\
\hline Malaysia & 2 \\
\hline Mexico & 2 \\
\hline Russia & 2 \\
\hline Serbia & 2 \\
\hline Turkey & 2 \\
\hline Saudi Arabia & 1 \\
\hline Arab Emirates & 1 \\
\hline Argentina & 1 \\
\hline Bangladesh & 1 \\
\hline Belgium & 1 \\
\hline Chile & 1 \\
\hline Colombia & 1 \\
\hline Cuba & 1 \\
\hline Egypt & 1 \\
\hline Iran & 1 \\
\hline Nigeria & 1 \\
\hline Netherlands & 1 \\
\hline Romania & 1 \\
\hline Slovenia & 1 \\
\hline Switzerland & 1 \\
\hline Tunisia & 1 \\
\hline Ukraine & 1 \\
\hline USA & 1 \\
\hline Vietnam & 1 \\
\hline
\end{tabular}

interest in the work carried out by others, this will limit progress and leave us far from achieving shared universal strategies that can serve to advance geological heritage into a scientifically healthy and mature discipline. Such a situation was observed in soil science in the late 1800 and early 1900s, when the failure to effectively communicate ideas across national boundaries was one factor that slowed the advancement of soil science as a field of study (Brevik et al., 2016) and in some cases continues to be an issue today (Rodrigo Comino et al., 2018).

The number of geoparks that have been established by country and continent as of the end of 2017 is shown in Tables 4 and 5. Twenty-four of the 35 countries that have established geoparks are in Europe, providing abundant and diverse geoparks opportunities within Europe. In total, $57 \%$ of the world's geoparks were found in Europe. Eastern Asia was also fairly well represented with $38 \%$ of the world's geoparks in six countries. China established more than three times more geoparks than any other individual country (27\% of all geoparks world-wide), and UNESCO (2017) recognized the European countries and China as the regions with the most interest in geoparks. Japan ranked 4th on the list of geoparks established by country, and Indonesia, Malaysia, the Republic of Korea, and Vietnam have also established geoparks. There are only four geoparks in North America (two in Canada and two in Mexico), two in South America (in Brazil and Uruguay), and one in Africa (Morocco). No geoparks have been established in Oceania. 
Table 2

The number of papers in which the name of a given country was included as part of the research as reported in Geoheritage Journal.

\begin{tabular}{|c|c|}
\hline Country & Number of studies \\
\hline Spain & 73 \\
\hline Italy & 67 \\
\hline France & 59 \\
\hline Germany & 55 \\
\hline Netherlands & 50 \\
\hline Belgium & 39 \\
\hline Greece & 39 \\
\hline Turkey & 33 \\
\hline Portugal & 31 \\
\hline Poland & 31 \\
\hline Bulgaria & 22 \\
\hline Iceland & 18 \\
\hline Austria & 17 \\
\hline Czech Republic & 14 \\
\hline Ireland & 14 \\
\hline Malta & 13 \\
\hline United Kingdom & 12 \\
\hline Australia & 12 \\
\hline Brazil & 11 \\
\hline China & 11 \\
\hline Cuba & 11 \\
\hline Ukraine & 10 \\
\hline Russia & 10 \\
\hline Argentina & 9 \\
\hline Chile & 8 \\
\hline Saudi Arabia & 8 \\
\hline Egypt & 7 \\
\hline Israel & 7 \\
\hline Bangladesh & 6 \\
\hline India & 5 \\
\hline Cameroon & 5 \\
\hline Nigeria & 5 \\
\hline Laos & 5 \\
\hline Fiji & 4 \\
\hline Mauritius & 4 \\
\hline Oman & 3 \\
\hline Serbia & 3 \\
\hline Morocco & 3 \\
\hline Colombia & 3 \\
\hline Vietnam & 3 \\
\hline Cambodia & 3 \\
\hline Republic of Korea & 2 \\
\hline New Zealand & 2 \\
\hline Iran & 2 \\
\hline Malaysia & 1 \\
\hline USA & 1 \\
\hline
\end{tabular}

This does not mean countries that do not have UNESCO geoparks such as Australia and the USA do not value parks and the conservation of nature; each of these countries has a vibrant national parks system. However, there does not seem to be a strong drive to establish geoparks in countries such as these at this time. Table 5 presents a particularly desolate scene. The geographical distribution of geoparks is biased and cannot represent a true picture of the Earth's geoheritage. This is true even though the UNESCO criteria used to establish the UNESCO Geoparks

Table 3

The number of studies as grouped by major geographic regions as reported in Geoheritage Journal.

\begin{tabular}{ll}
\hline Continent & Number of studies \\
\hline Europe & 82 \\
European Union $^{\mathrm{a}}$ & 41 \\
North and South America $_{\text {Asia }}$ & 36 \\
Africa & 23 \\
Oceania & 23 \\
\hline
\end{tabular}

${ }^{a}$ The European Union (EU) was also looked at separately from the rest of Europe to determine if there were any research trends by membership or lack thereof in the EU. The Europe number also includes studies by EU countries. label tries to help/encourage developing countries to improve their living conditions and progress towards sustainable development. Likewise, it is noteworthy that European countries that have large tourism industries have achieved great success in getting the UNESCO labels, which will help them to diversify and strengthen their offerings to a greater number of visitors and generate economic income in the future. Within the geoparks concept, the preservation of geomorphological heritage has aroused much greater interest than other natural objects included in the concept of geodiversity (e.g. Reynard et al., 2007; Coratza and Giusti, 2005; Testa et al., 2013; Melelli et al., 2017) with some exceptions such as paleontological sites (e.g. Sá dos Santos et al., 2016).

There are interesting similitudes and differences between the publication data from Geoheritage Journal (Tables 1-3) and the UNESCO geoparks data (Tables 4 and 5). For instance, the European expert community is the most active both in the number of papers published and the number of geoparks established, with the southern European countries being more active than the northern ones. In contrast, the ratio of papers published in Geoheritage by Chinese experts is low with respect to the number of geoparks in that country. The opposite trend occurs with South America, and specially Brazil, where authors have been active publishing in Geoheritage but few geoparks have been created, and despite interest in the research community there are no geoparks in Australia. The data indicates a lack of equitability between the scientific (papers) and pragmatic (number of geoparks) progress among countries and continents.

\subsection{Statistical evaluation of key terms}

The choice of some generic terms (such as geology, mineral, soils, etc.) that appear in Tables 6-8 necessarily suffer from certain arbitrariness. They were selected as reference words to show the current relevance of those most directly related to the objectives of this paper (geodiversity, geoheritage, pedodiversity, etc.). However, if we analyze the number of times each word appears in the tables and apply certain basic indexes commonly used in diversity analysis we observe some interesting regularities. In all of them the distributions conform to the hollow curve, as is usual in pedodiversity and biodiversity studies (see Ibáñez and Bockheim, 2013 and several chapters there in). Furthermore, in most of the cases the best fits occur with log normal and logarithmic distributions, instead of geometric distributions and the so termed "broken stick" model, as is also the rule in biodiversity and pedodiversity analyses. The equitability is in general a little higher, but is also in the expected range of the above mentioned diversities. Likewise in all cases the data shown in these tables fits a power law better than a linear distribution (Table 9) as is ubiquitous in biodiversity and pedodiversity analysis but also in other many structures and processes of nature (e.g. Schroeder, 1992) and in natural languages as described by Zipf's law (word frequency distributions for a large enough piece of text) (Moreno-Sánchez et al., 2016). Although the data provided by the tables are inconclusive, whether or not Zipf's law could be extended to key term searches in the Internet, or any type of data mining, would be an interesting line of study.

\subsection{Importance to understanding the history of geodiversity studies}

This type of basic datamining can offer great insights regarding the history of a field. For example, Sharples (1993) has been credited with being the first to coin the term geodiversity in 1993 (Gray, 2004, 2008). However, the search in Scopus showed that the term geodiversity first appeared in the scientific literature more than ten years before Sharples' work (see Karjalainen (1983) and references there in). Also, while Sharples (1993) focused attention on geoconservation, that same year De-Alba et al. (1993) conducted the first study that simultaneously quantified geodiversity as a function of lithodiversity, landform diversity and pedodiversity, the three topics that are most often included in the definition of geodiversity. In a similar 


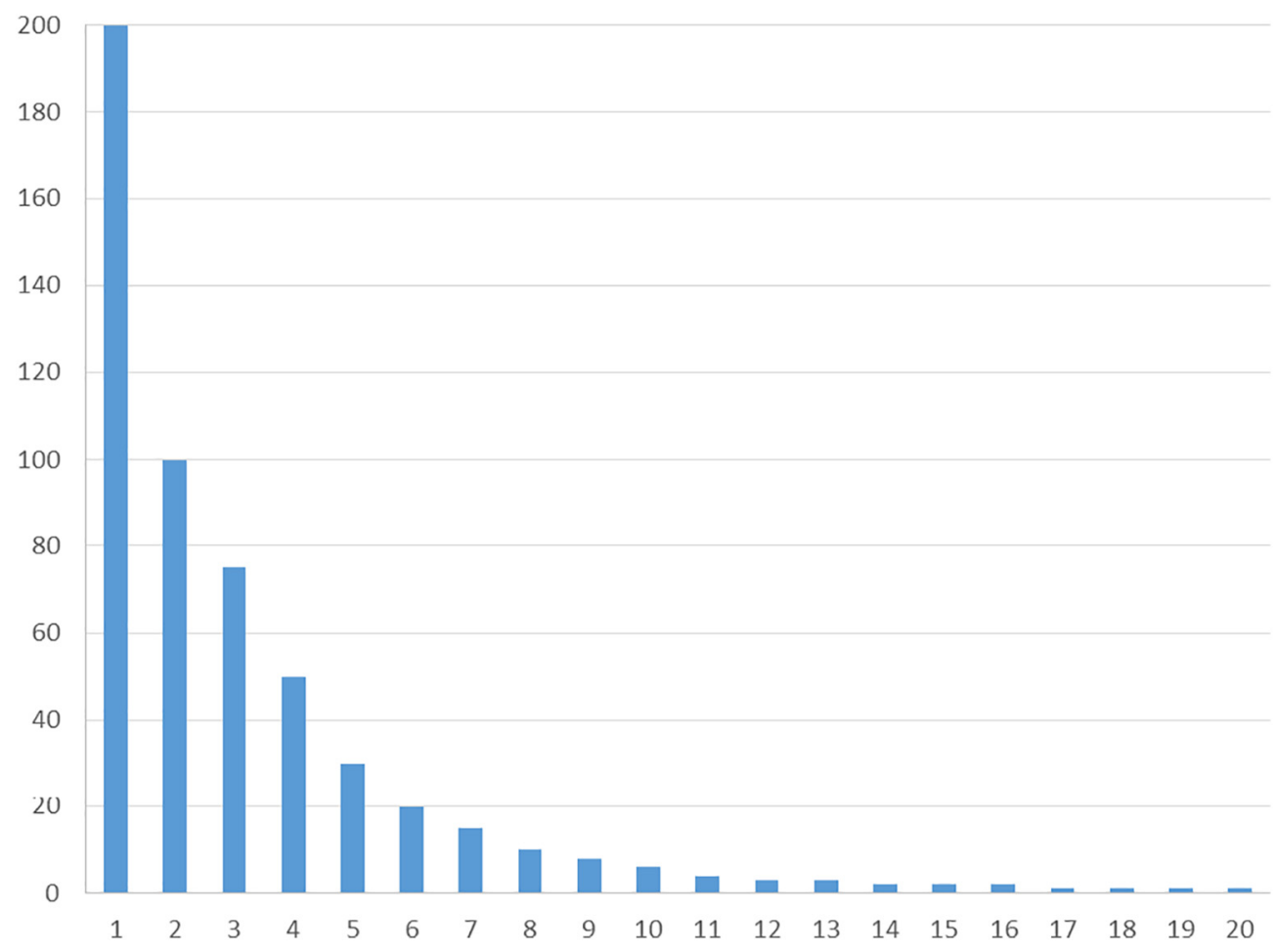

Fig. 1. An idealized hollow curve.

fashion, the word pedodiversity was coined by McBratney (1992) in parallel with biodiversity some months after the Rio Summit that launched the popularity of the word biodiversity. However, earlier studies on the quantification of soil diversity were conducted by the Russian scientist Fridland as well as Ibáñez and coworkers (see Ibáñez, 2014 and references therein). Therefore, reviews such as the one conducted in this study have the ability to clarify the history and development of geodiversity and pedodiversity studies.

\subsection{Classification of papers using Geoheritage Journal}

Results of the classification of papers are shown in Table 10. A large portion of the papers published in Geoheritage Journal were case studies (83\%), while there were relatively few papers that proposed and debated theoretical and methodological aspects of geodiversity (7\%). Zwoliński et al. (2018) also determined that few authors have addressed methodological issues. Educational, thematic, review papers,

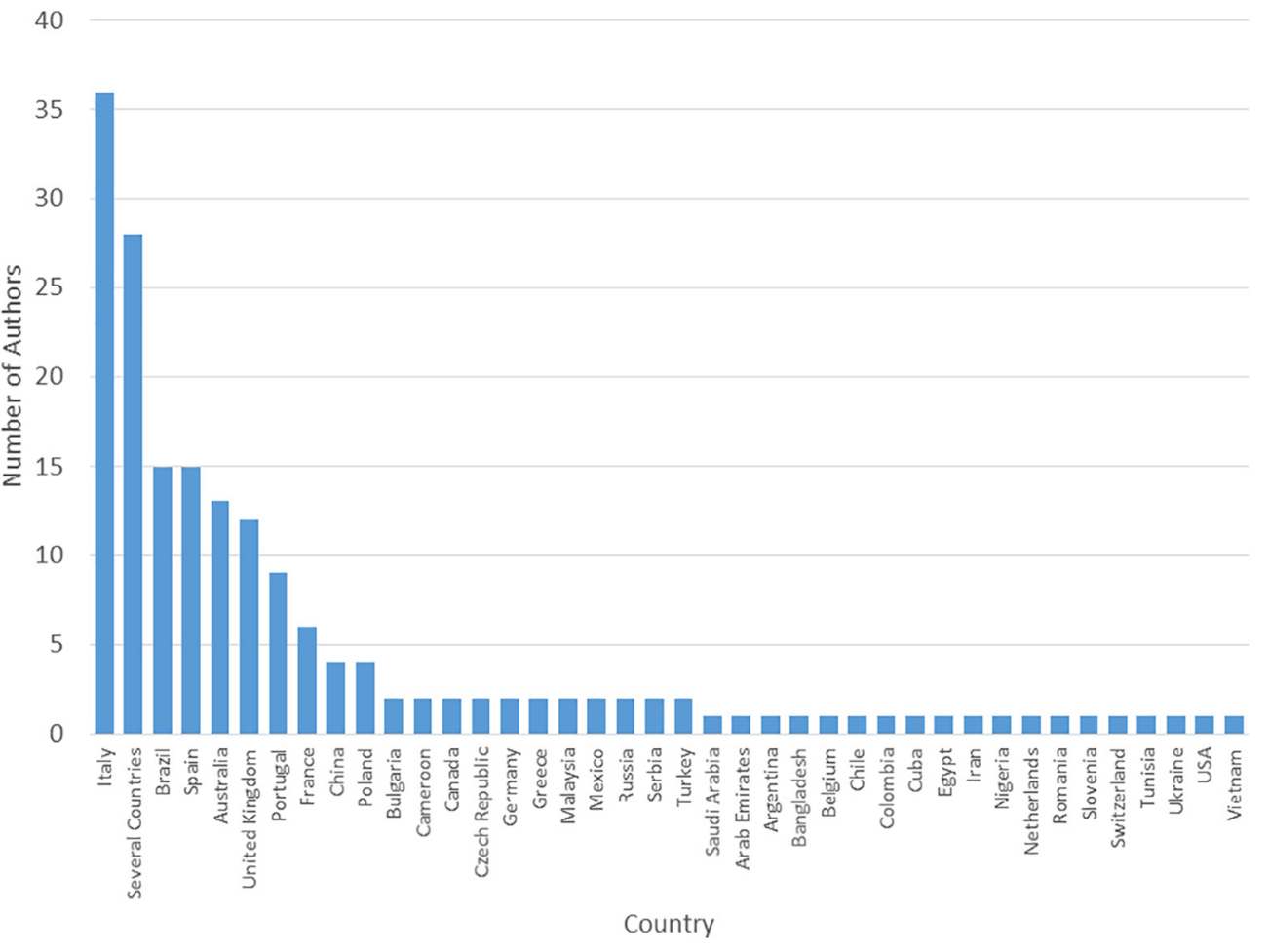

Fig. 2. The number of authors who have published papers in Geoheritage Journal by country. 


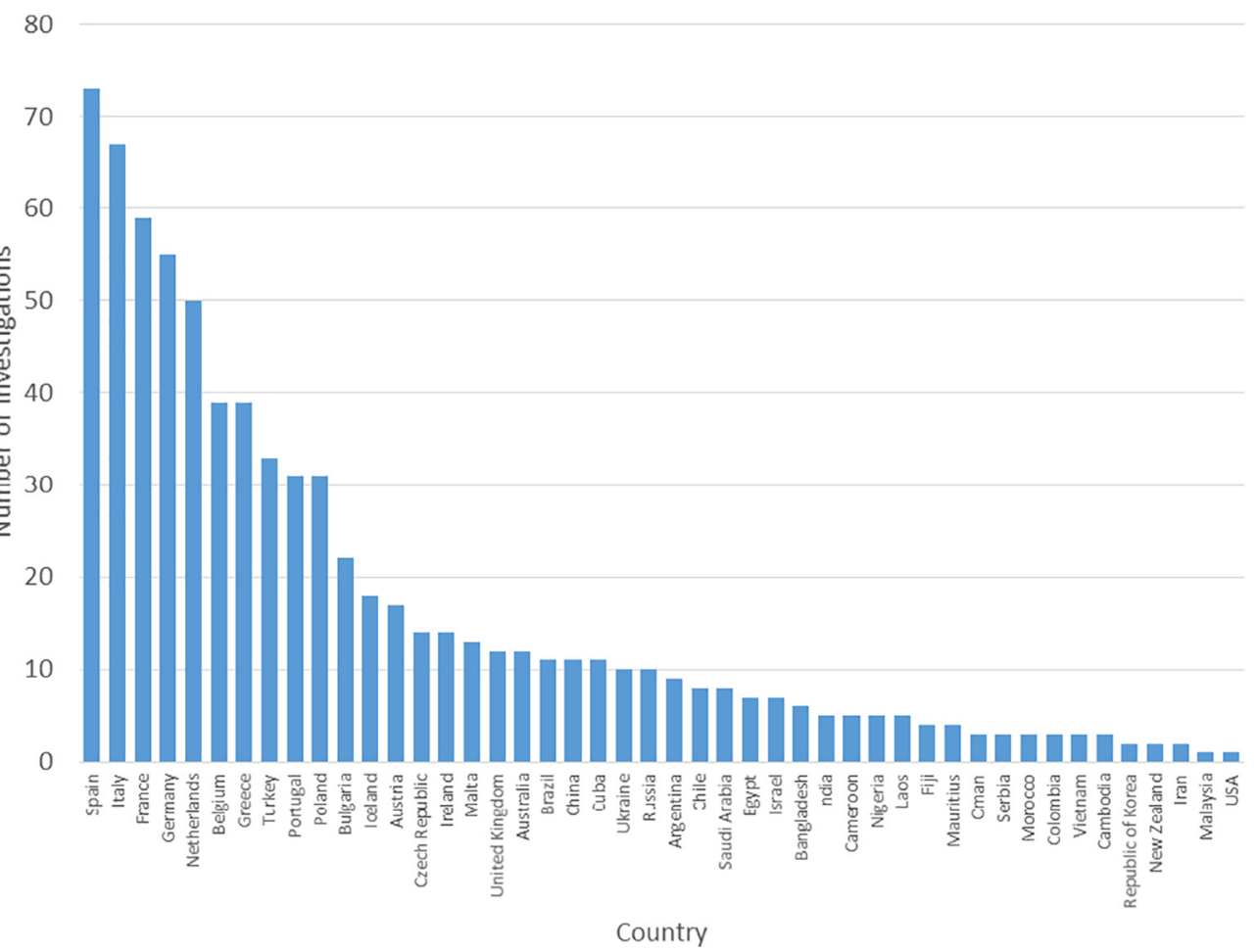

Fig. 3. The number of times a given country was included as part of a research project reported on in Geoheritage Journal.

and other types of papers were published in very low amounts (1-3\% of total papers).

3.5. Key terms in Geoheritage Journal, Scopus, and Google Scholar databases

The frequency of key terms use related to geodiversity studies in Geoheritage Journal, Scopus, and Google Scholar are shown
Tables 6-8, respectively. These key terms have been further subdivided into papers focused on diversity studies into geology, geomorphology, paleontology, and pedology. However, it is important to note the term geodiversity can be applied to rocks, landforms, or fossils, etc. The terms geodiversity and geosites are used in a broad sense in many instances. Certain key terms commonly occurred in all of the databases for a given focus. The key terms "geoheritage", "geodiversity" or "geological diversity", and "geosites" were the five most common key

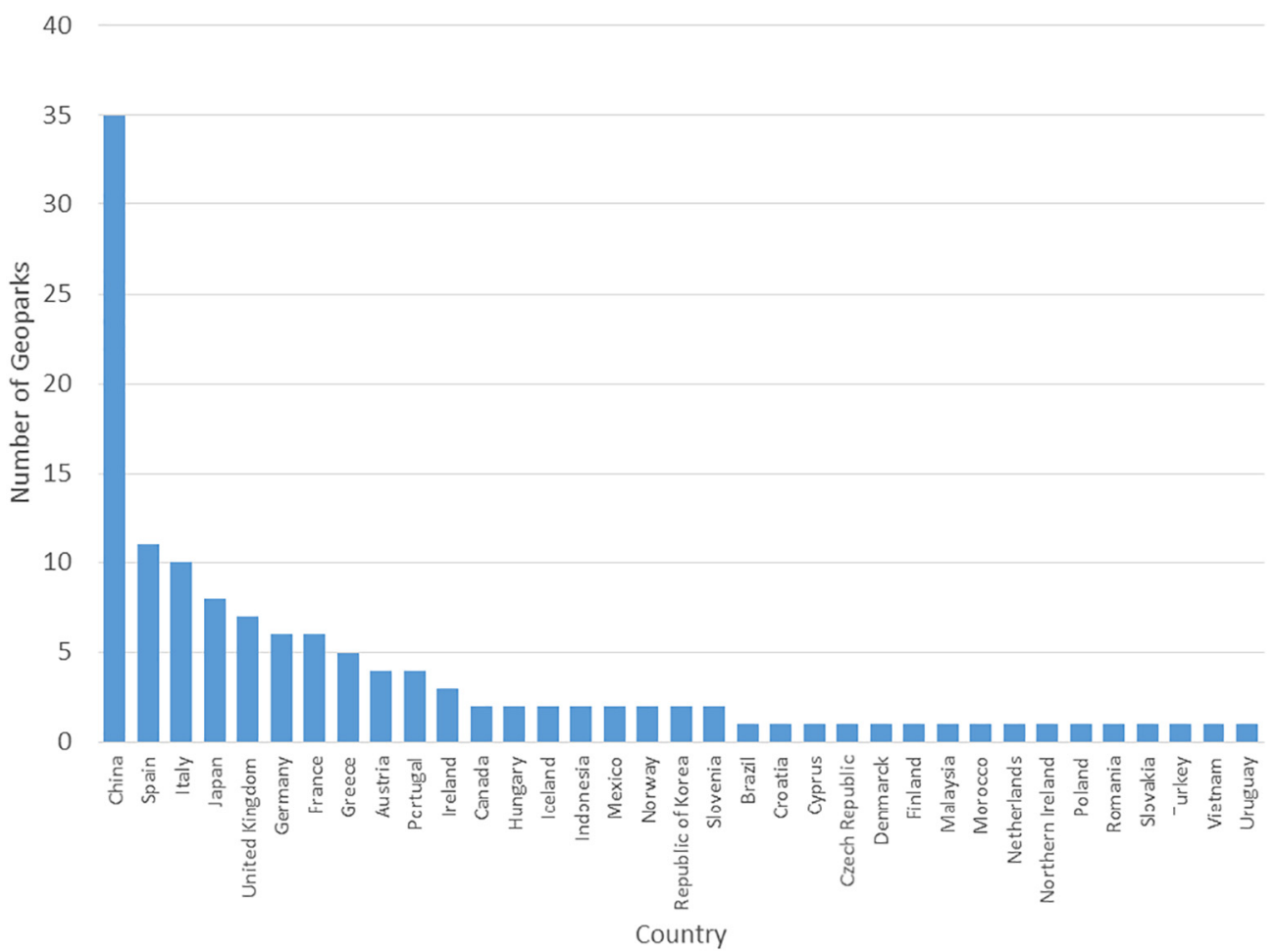

Fig. 4. The number of geoparks by country. 
Table 4

The number of geoparks by country (UNESCO, 2017).

\begin{tabular}{|c|c|}
\hline Country & Number of geoparks \\
\hline China & 35 \\
\hline Spain & 11 \\
\hline Italy & 10 \\
\hline Japan & 8 \\
\hline United Kingdom $^{a}$ & 7 \\
\hline Germany $^{\mathrm{a}}$ & 6 \\
\hline France & 6 \\
\hline Greece & 5 \\
\hline Austria $^{a}$ & 4 \\
\hline Portugal & 4 \\
\hline Ireland $^{\mathrm{a}}$ & 3 \\
\hline Canada & 2 \\
\hline Hungary $^{\mathrm{a}}$ & 2 \\
\hline Iceland & 2 \\
\hline Indonesia & 2 \\
\hline Mexico & 2 \\
\hline Norway & 2 \\
\hline Republic of Korea & 2 \\
\hline Slovenia $^{\mathrm{a}}$ & 2 \\
\hline Brazil & 1 \\
\hline Croatia & 1 \\
\hline Cyprus & 1 \\
\hline Czech Republic & 1 \\
\hline Denmark & 1 \\
\hline Finland & 1 \\
\hline Malaysia & 1 \\
\hline Morocco & 1 \\
\hline Netherlands & 1 \\
\hline Northern Ireland ${ }^{\mathrm{a}}$ & 1 \\
\hline Poland $^{\mathrm{a}}$ & 1 \\
\hline Romania & 1 \\
\hline Slovakia $^{\mathrm{a}}$ & 1 \\
\hline Turkey & 1 \\
\hline Vietnam & 1 \\
\hline Uruguay & 1 \\
\hline Total & 130 \\
\hline
\end{tabular}

Diversity Statistic S or Richness $=35$; $\mathrm{H}$ or Shannon Diversity Index = 28,103; E or equitability $=0.807$.

a Transnational UNESCO Global Geoparks have been assigned to each of the involved countries.

terms for diversity studies in geology. "Landforms", "geomorphosites", "relief", and "geomorphology" were common key terms across all three databases for diversity studies in geomorphology. "Fossils", "paleontological heritage", "diversity of fossils" and "fossil diversity", and "dinosaurs" were all common key terms in paleontological diversity studies across all three databases. And studies focused on soil diversity frequently used the key terms "soil erosion", "soil diversity", and "paleosols". However the relative abundance of papers focused on soil diversity (pedodiversity) was surprisingly rare.

An analysis of the scientific studies published in the Scopus database does not give the exact same perspective with respect to the results obtained by analyzing Geoheritage Journal and Google Scholar, although there are similarities. The relative difference between the abundances of the papers that contemplate geodiversity and pedodiversity is reduced when investigating papers included in Scopus as compared to those indexed in Google Scholar. Pedodiversity studies were

Table 5

The number of Geoparks by continent (UNESCO, 2017).

\begin{tabular}{ll}
\hline Continent & Number of studies \\
\hline Europe & 74 \\
Asia & 49 \\
North America & 4 \\
South America & 2 \\
Africa & 1 \\
Oceania & 0 \\
\hline
\end{tabular}

Diversity Statistics; Richness = 6; $\mathrm{H}$ (Shannon Diversity Index $)=$ 0.85623 ; E or equitability $=0.47787$.
Table 6

The number of times that key terms related to geodiversity studies were used in Geoheritage Journal, divided by geoscience subfield.

\begin{tabular}{|c|c|}
\hline \multicolumn{2}{|l|}{ GEOLOGY } \\
\hline Geology & 183 \\
\hline Geoheritage & 183 \\
\hline Geosites & 124 \\
\hline Geodiversity & 110 \\
\hline Minerals & 95 \\
\hline Mineral diversity & 68 \\
\hline Mineral preservation & 64 \\
\hline Lithology & 34 \\
\hline Lithologies & 26 \\
\hline Lithological diversity & 23 \\
\hline Geological diversity & 1 \\
\hline \multicolumn{2}{|l|}{ GEOMORPHOLOGY } \\
\hline Landforms & 100 \\
\hline Geomorphology & 94 \\
\hline Relief & 51 \\
\hline Geomorphosites & 44 \\
\hline Geomorphosite & 35 \\
\hline Geomorphological diversity & 5 \\
\hline Diversity of landforms & 3 \\
\hline Diversity of relief & 3 \\
\hline Geoforms & 2 \\
\hline Diversity of geoforms & 2 \\
\hline Relief diversity & 0 \\
\hline \multicolumn{2}{|l|}{ PALEONTOLOGY } \\
\hline Fossils & 108 \\
\hline Paleontological heritage & 46 \\
\hline Dinosaur & 34 \\
\hline Paleontological sites & 14 \\
\hline Diversity of fossils & 2 \\
\hline Fossil diversity & 1 \\
\hline Paleontological diversity & 0 \\
\hline Paleontological conservation & 0 \\
\hline \multicolumn{2}{|l|}{ SOIL SCIENCE } \\
\hline Soils & 93 \\
\hline Soil features & 14 \\
\hline Soil erosion & 8 \\
\hline Pedology & 7 \\
\hline Soil types & 7 \\
\hline Paleosols & 5 \\
\hline Soil diversity & 3 \\
\hline Soil science & 3 \\
\hline Conservation of soils & 2 \\
\hline Soil conservation & 2 \\
\hline Soil sites & 2 \\
\hline Diversity of soils & 1 \\
\hline Erosion of soils & 1 \\
\hline Soil directive & 1 \\
\hline Soil heritage & 1 \\
\hline Pedodiversity & 0 \\
\hline Pedosites & 0 \\
\hline Preservation of soils & 0 \\
\hline Soil preservation & 0 \\
\hline Soil units & 0 \\
\hline
\end{tabular}

surprisingly rare in Google Scholar, although not practically nonexistent as was the case in Geoheritage Journal. This fact is surprising because geodiversity should incorporate multiple earth science disciplines and thus incorporate a number of researchers, whereas pedodiversity interest is focused in a single discipline that is, in fact, part of geodiversity. However, this result indicates that there is much more gray literature on geodiversity in general than there is on pedodiversity, which affects a subset of the experts in geodiversity studies in the broadest sense of the term. We reach this conclusion because Google Scholar contains much more gray literature (graduate theses, books and book chapters, conference proceedings, etc.) than Scopus, which is more focused on peer-reviewed journal articles. It seems that pedologists are focused mainly on scientific studies that are published in indexed journals, whereas a considerable part of the geodiversity literature is found in other more applied outlets such as those produced by government 
Table 7

The number of times that key terms related to geodiversity, geoheritage and pedodiversity studies were used in Scopus, divided by geoscience subfield.

\begin{tabular}{|c|c|}
\hline \multicolumn{2}{|l|}{ GEOLOGY } \\
\hline Geodiversity & 1150 \\
\hline Geotourism & 964 \\
\hline Geoheritage & 887 \\
\hline Geosites & 755 \\
\hline Geodiversity \& biodiversity & 400 \\
\hline Mineral diversity & 400 \\
\hline Geomorphosites & 377 \\
\hline Geodiversity \& geoheritage & 361 \\
\hline Rock diversity \& diversity of rocks & 285 \\
\hline Geodiversity \& geosites & 280 \\
\hline Geological diversity \& geologic diversity & 193 \\
\hline Geodiversity \& reserves & 165 \\
\hline Sediment diversity & 115 \\
\hline Diversity of minerals & 114 \\
\hline Geoheritage and reserves & 101 \\
\hline Mineral(s) preservation & 98 \\
\hline Lithological diversity & 79 \\
\hline Geoheritage conservation & 48 \\
\hline Geosites inventory & 39 \\
\hline Lithodiversity & 29 \\
\hline Geoheritage reserves & 6 \\
\hline \multicolumn{2}{|l|}{ GEOMORPHOLOGY } \\
\hline Geodiversity \& landforms & 329 \\
\hline Geoheritage \& geomorphosites & 195 \\
\hline Geodiversity \& geomorphosites & 162 \\
\hline Geomorphic (geomorphological) diversity & 147 \\
\hline Geomorphosites \& geotourism & 146 \\
\hline Diversity of landform(s) & 27 \\
\hline Landforms diversity & 17 \\
\hline Diversity of relief & 11 \\
\hline Relief diversity & 3 \\
\hline Geomorphological preservation & 1 \\
\hline Diversity of geoforms & 0 \\
\hline \multicolumn{2}{|l|}{ PALEONTOLOGY } \\
\hline Fossil diversity & 344 \\
\hline Diversity of fossils & 248 \\
\hline Paleontological heritage & 67 \\
\hline Paleontological diversity & 1 \\
\hline \multicolumn{2}{|l|}{ SOIL SCIENCE } \\
\hline Soil \& diversity & 229,357 \\
\hline Soil \& biodiversity & 12,525 \\
\hline Diversity \& soil types & 11,898 \\
\hline Diversity of soils & 6919 \\
\hline Soil diversity & 1623 \\
\hline Pedodiversity & 426 \\
\hline Soil reserves & 176 \\
\hline Geodiversity \& pedodiversity & 35 \\
\hline Geodiversity \& paleosol(s) & 12 \\
\hline Pedotourism & 0 \\
\hline Pedodiversity inventory & 0 \\
\hline
\end{tabular}

Richness $=46 ; \mathrm{H}$ (Shannon Diversity Index $)=2.18$; equitability $=0.57$.

agencies during the creation and promotion of geoparks and the exploitation of their economic value (geotourism).

It was found that most or all of the papers in Scopus used the terms geodiversity, geoheritage, geotourism, and to a lesser extent geosites more or less at the same time. This suggests that practical purposes of economic interest are enhancing the publication of such studies, in contrast to the pedologists who are more interested in "soil diversity" analysis. Furthermore, plotted curves of increases in the numbers of papers through time demonstrate this trend, but sequentially, from the most basic terms to the more applied ones. For example, geodiversity curves began to grow slowly between the years 1998-2001, then increased, and showed exponential growth from 2009 (Fig. 5); pedodiversity followed a similar trend (Fig. 6). The geoheritage curve shows the same pattern but the slow part of the growth curve persisted until 2005 before beginning exponential growth, also around 2009 (Fig. 7). Geoparks showed a very sudden move into exponential growth in the late 1990s (Fig. 8), suggesting a unique and sudden driving force that
Table 8

The number of times that key terms related to geodiversity, geoheritage and pedodiversity studies were used in Google Scholar, divided by geoscience subfield.

\begin{tabular}{|c|c|}
\hline \multicolumn{2}{|l|}{ GEOLOGY } \\
\hline Geology (geological) & 5310 \\
\hline Geoheritage & 4790 \\
\hline Minerals & 2840 \\
\hline Geological diversity & 1990 \\
\hline Geosites & 1400 \\
\hline Lithologies & 940 \\
\hline Lithology & 934 \\
\hline "Lithological diversity" & 38 \\
\hline "Diversity of minerals" & 24 \\
\hline "Mineral diversity" & 7 \\
\hline "Mineral preservation" & 0 \\
\hline \multicolumn{2}{|l|}{ GEOMORPHOLOGY } \\
\hline Erosion & 3330 \\
\hline Geomorphology & 2730 \\
\hline Relief & 2220 \\
\hline Landforms & 2010 \\
\hline Geomorphosites & 573 \\
\hline Geoforms & 155 \\
\hline Geomorphological diversity & 98 \\
\hline Diversity of landforms & 50 \\
\hline Relief diversity & 25 \\
\hline Diversity of relief & 8 \\
\hline \multicolumn{2}{|l|}{ PALEONTOLOGY } \\
\hline Fossils & 1660 \\
\hline Dinosaur & 340 \\
\hline Paleontological heritage & 53 \\
\hline Diversity of fossils & 10 \\
\hline Fossils diversity & 1 \\
\hline Paleontological diversity & 1 \\
\hline \multicolumn{2}{|l|}{ SOIL SCIENCE } \\
\hline Soil erosion & 543 \\
\hline Soil conservation & 194 \\
\hline Pedodiversity & 129 \\
\hline Soils & 93 \\
\hline Soil diversity & 87 \\
\hline Paleosols & 79 \\
\hline Diversity of soils & 24 \\
\hline Soil features & 14 \\
\hline Soil sites & 13 \\
\hline Erosion of soils & 10 \\
\hline Soil preservation & 10 \\
\hline Conservation of soils & 7 \\
\hline Pedology & 7 \\
\hline Soil types & 7 \\
\hline Soil directive & 7 \\
\hline Soil science & 3 \\
\hline Pedosites & 0 \\
\hline
\end{tabular}

Richness $=42 ; \mathrm{H}$ (Shannon Diversity Index $)=2.64$; equitability $=0.71$.

triggered an interest in the subject within the scientific community. It is notable that this coincides with the deliberations and approval of the Geoparks Programme by the UNESCO in 1999.

\subsection{Considerations in the key terms analysis}

Tables showing simple words or a combination of words provide interesting information, but these key terms should also be carefully evaluated. Many words can appear in research without being the focus of

Table 9

The number of times that each term was used in the Google Scholar and Scopus tables.

\begin{tabular}{|c|c|c|}
\hline Distribution model & Linear fit & Power law fit \\
\hline Geodiversity single term & 0.64 & 0.66 \\
\hline Geodiversity and other terms & 0.62 & 0.84 \\
\hline Geoheritage and other terms & 0.36 & 0.93 \\
\hline Scopus data ${ }^{a}$ & 0.25 & 0.81 \\
\hline
\end{tabular}

a Deleting the highest term: soil \& diversity. 
Table 10

Classification of papers by general topic in Geoheritage Journal.

\begin{tabular}{ll}
\hline Topic & Number of papers \\
\hline Case studies of local interest & 122 \\
Cast studies of general (broad) interest & 30 \\
Theoretical/methodological & 14 \\
Educational & 6 \\
Thematic & 3 \\
Review paper & 2 \\
Others & 6 \\
\hline
\end{tabular}

that research or with a variety of meanings. Some words, such as "diversity", are too generic and widely used, being utilized by writers to designate technical aspects or simply as synonyms of concepts different from those analyzed here. The reader should take such limitations into account. Logically, the more generic the database is the more carefully information gathered from it should be scrutinized. For this reason the most reliable conclusions in this study can be drawn from the data mining of the Geoheritage Journal's papers, followed by Scopus, with the information provided by Google Scholar being the most ambiguous. This is because the information in Geoheritage and Scopus is specifically focused on geoheritage, geodiversity and pedodiversity whereas the Google Scholar database provides more ambiguous information about the topics treated, with many of the references identified being gray literature.

The use of single word searches in the Geoheritage Journal database must also be approached with caution. For example, three terms widely used in papers published in this journal are erosion, diversity and soils. The word erosion appears in many papers, but in most of the cases it was not related to any interest in soils on the part of the author(s). For example, in several papers the authors call the readers' attention to the damage that current erosion processes could cause to the preservation of certain structures of geological interest (Panizza, 2009; Hjort et al., 2015). The use of the term erosion in a manuscript may also imply positive connotations with respect to the preservation of landform geodiversity; some papers call attention to the need to preserve badlands landscapes in view of the high biodiversity harbored in gullies of different ages and sizes. For this reason erosion appeared in the search even more than the word soil. In both examples above the papers that discussed erosion were not related to soils and pedodiversity preservation. Regrettably the word soil also appears in a large number of articles because the authors discuss definitions of geodiversity at the beginning of their papers, and that definition almost always includes soils (Huston, 1994; Sharples, 1993; Gray, 2004). However, most of these manuscripts do not actually address the importance of soils as part of geoheritage in the research they report. Only one paper in Geoheritage published during the time covered by this study (Conway, 2010) had a strong focus on soil preservation, and even this paper failed to mention pedodiversity analysis and the efforts of pedologists to preserve "pedoheritage" or "soil heritage". There is also ambiguity with respect to the use of important terms in physical geography, probably due to the different uses of these terms by different national schools. While geomorphology is the study of the morphology and genesis of landforms, many geomorphology papers in Geoheritage Journal made use of physiographic information only. GIS and related technologies permit easy use of certain landform metrics. For example, a more or less flat relief could be formed by different process and as a result the soil coverage over this area could be significantly different from place to place across the landscape, such as occurs with peneplains, pediplains, etchplain, etc. (King, 1983; Gerrard, 1992) or in the flat bottoms of ancient lakes (Brevik and Fenton, 1999). The same situation can occur with their intrinsic geoheritage values. A physiographic approach estimated by landscape metrics via GIS software cannot replace sound scientific classification. Beyond such limitations, the results obtained are interesting to analyze their use in the three datasets in a comparative way.

\subsection{Some gaps in available studies - future needs}

Probably the most immediate gap that was identified by this review was the uneven geographic distribution of geodiversity studies (Tables 1-3) and geoparks (Tables 4 and 5) at the beginning of 2017. If we are going to truly understand global geodiversity it is important

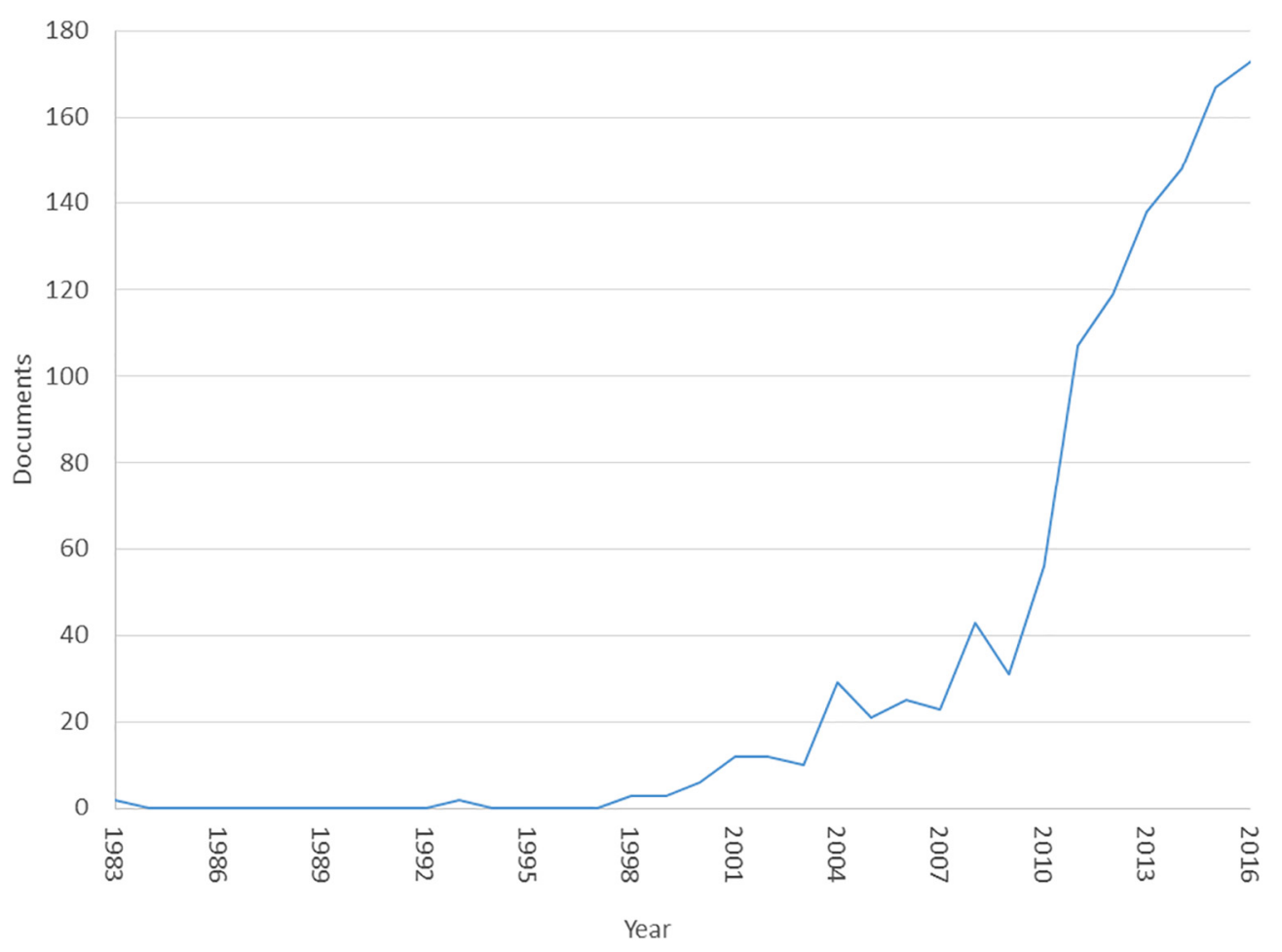

Fig. 5. The use of the term "geodiversity" over time. 


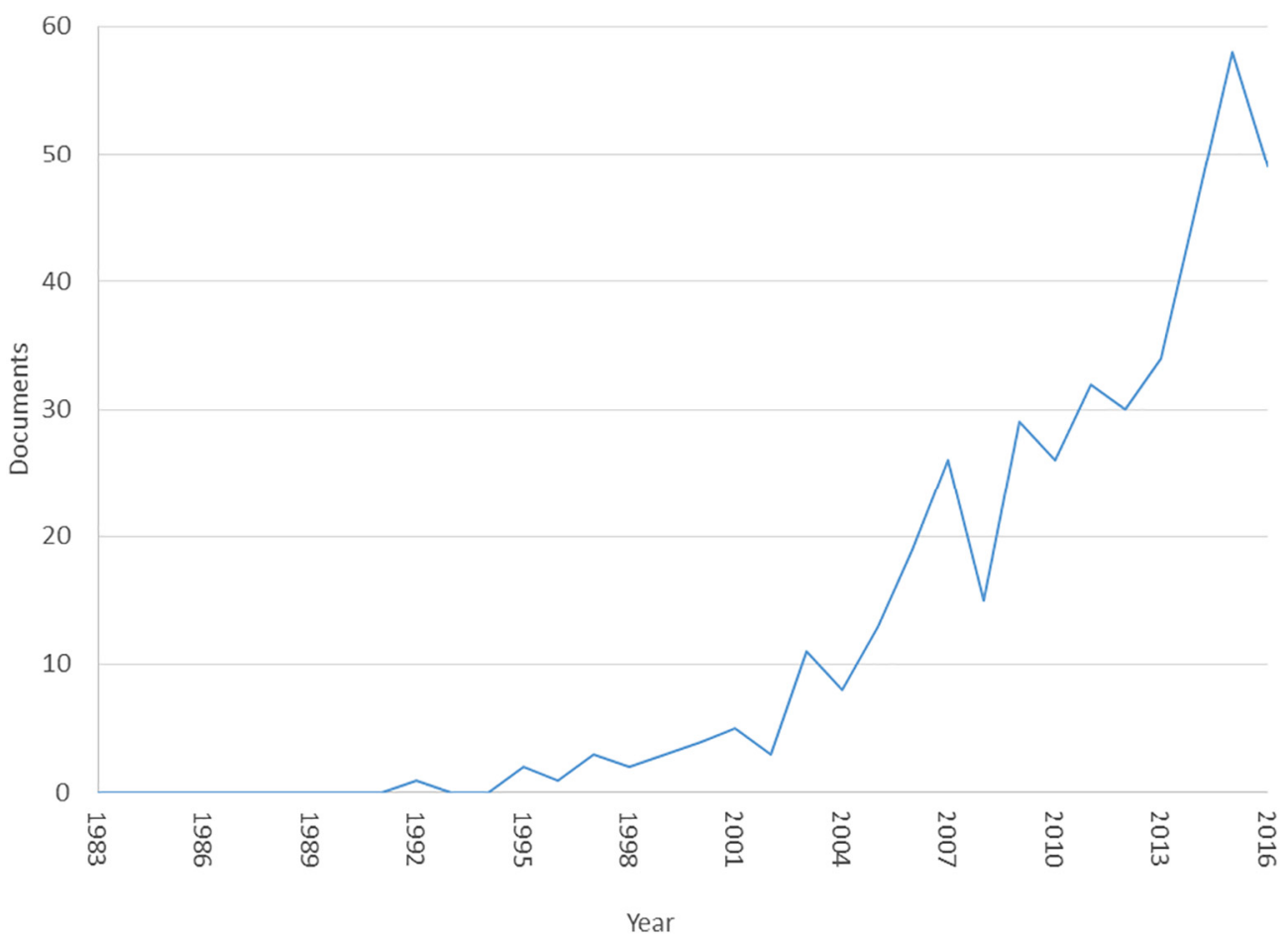

Fig. 6. Use of the term "pedodiversity" over time.

that a broader and more representative distribution of such studies is completed (Scheffer, 1999).

There are a plethora of papers and books concerning the relationships between soils and landforms (e.g. Ollier and Pain, 1996; Birkeland, 1999; Brevik and Fenton, 1999), soils and lithology (e.g. Zinck et al., 2016), lithology and landforms (e.g. Bridges, 1990; Zink, 2013), geology and plants (e.g. Kruckeberg, 2002), geology and soils (e.g. Kolay, 2010; Brevik and Miller, 2015; Zinck et al., 2016), landforms and vegetation (e.g. Howard and Mitchell, 1985; Stallins, 2006), and soils and vegetation (e.g. Jobbagy and Jackson, 2000; Eyre, 2013; Ibáñez et al., 2016). However, the literature reporting the relationships among the respective diversities of these natural bodies is scarce and recent. Most of these papers show exciting relationships between pedodiversity and aboveground and soil biodiversity, landforms, lithodiversity and so on (see bibliography in Ibáñez and Bockheim, 2013, Ibáñez, 2014). There is great interest in the scientific literature

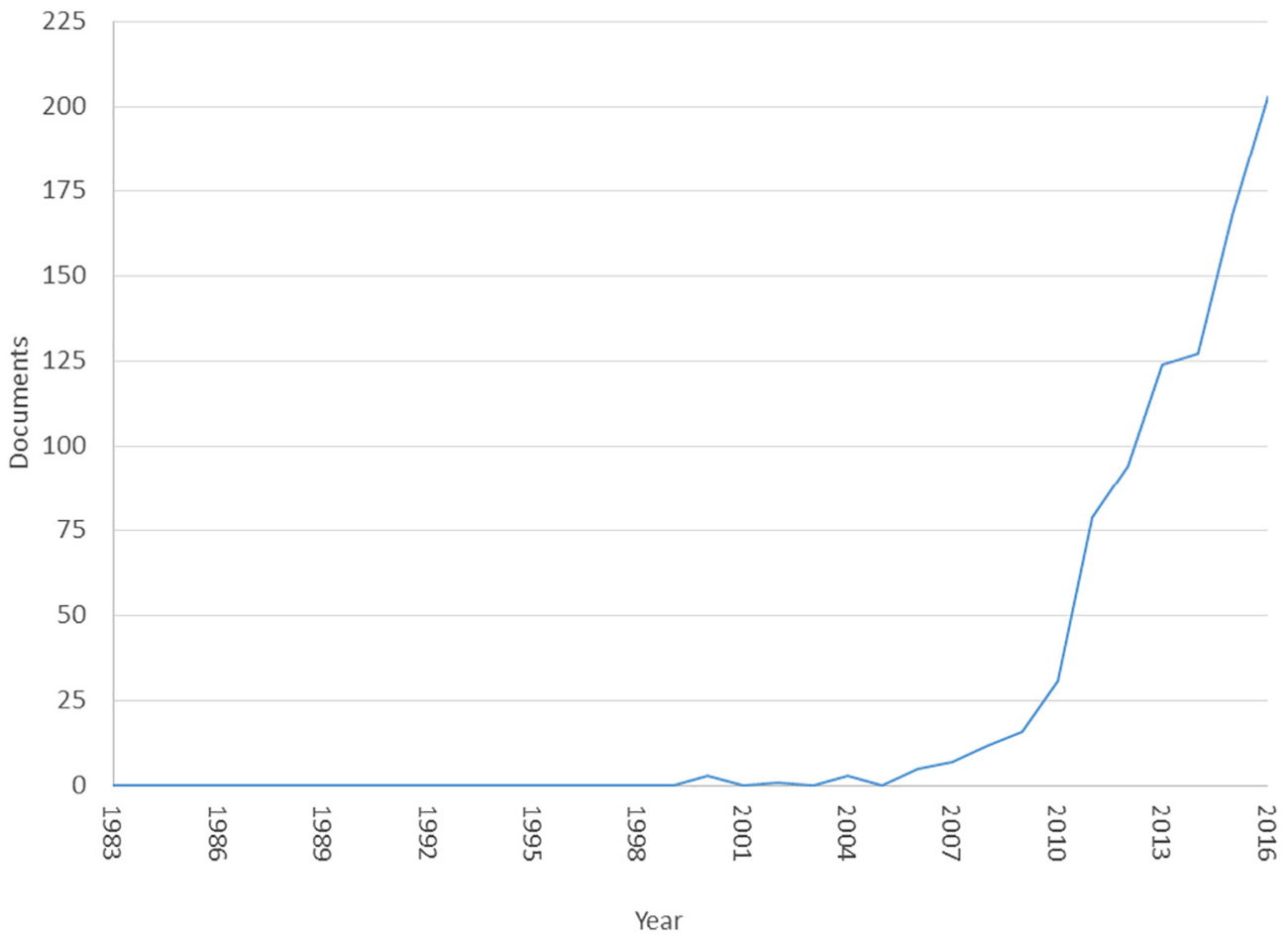

Fig. 7. The use of the term "geoheritage" over time. 


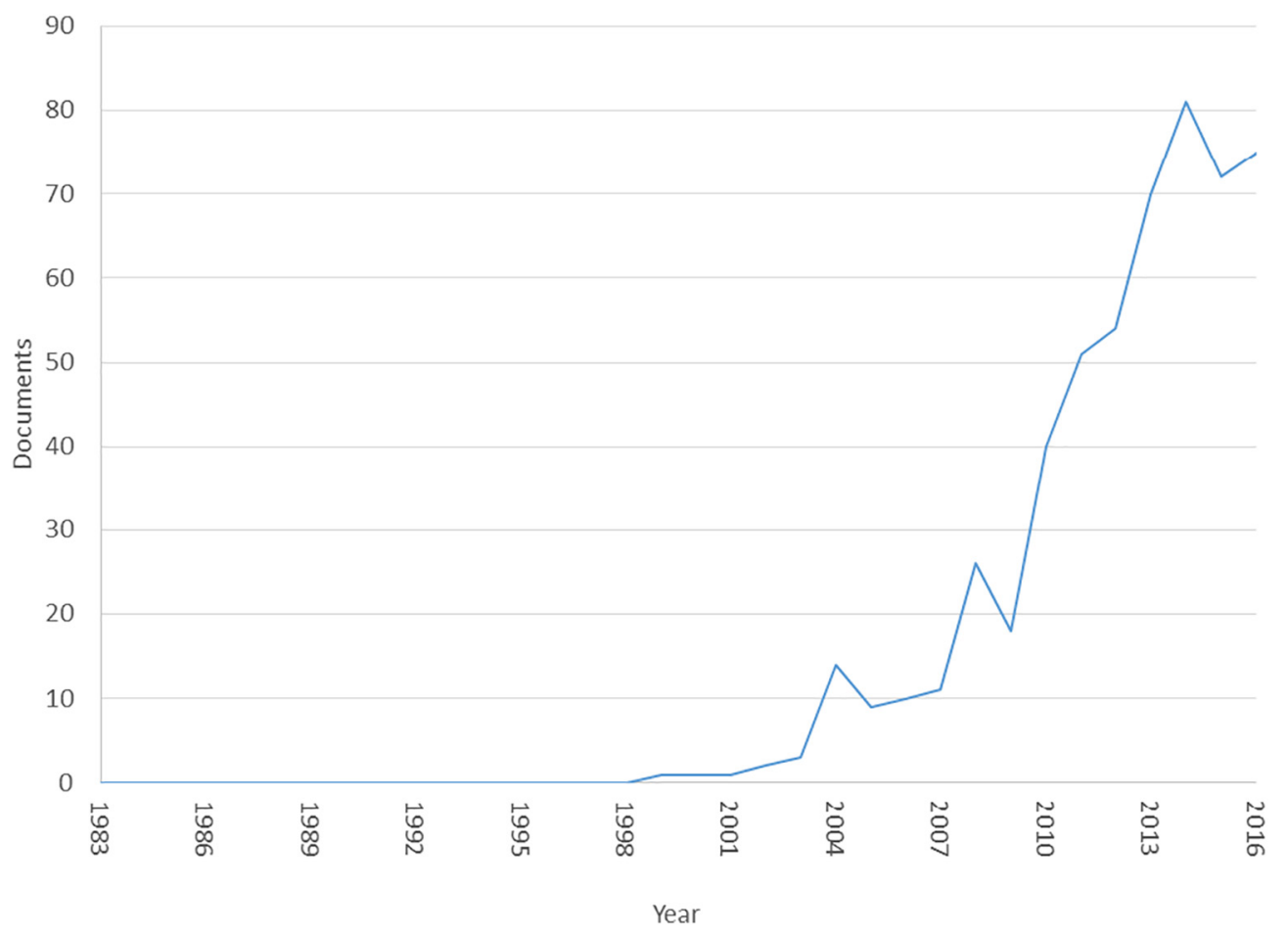

Fig. 8. Use of the term "geoparks" over time.

on biotic and abiotic surrogate indicators of biodiversity. In fact many researchers contend that the exhaustive corroborated diversity-area relationship (that conforms to a power law) hides another more predictive power: biodiversity-habitat heterogeneity relationships (e.g. Harner and Harper, 1976; Johnson and Simberloff, 1974; Williamson, 1981; Hupp, 1990; Triantis et al., 2003; Ibáñez and Feoli, 2013; Ibáñez et al., 2014, among many others). All these diversity-area relationships datasets also fit to a power law (see bibliography in Ibáñez and Bockheim, 2013, Ibáñez, 2014). Consequently, there is sufficient evidence to justify researching whether the spatial patterns of biodiversity are idiosyncratic or are also a characteristic of abiotic resources. If geodiversity patterns could be the driving forces behind the biodiversity patterns, this would open a fascinating and unexplored research field to expand the horizons of geodiversity studies, which are currently restricted to the protection of geological heritage (with a few exceptions such as mineral diversity). That would make new opportunities and funds available to experts in geology, landforms and soils. At this date the bibliography on this topic is in its infancy (e.g. Pemberton, 2007; Parks and Mulligan, 2010; Matthews, 2014; Bétard et al., 2017). For example, in some environments and lithological materials rainfall produces soil erosion and eroded sedimentary sequences inducing the development of badlands landscapes, increasing the biodiversity of such sites (Gallart et al., 2013). Some human practices can interfere with badlands formation when these should be preserved as part of biodiversity and geodiversity heritages (Phillips, 1998).

This review of the literature showed that there is currently a lack of universal criteria utilized to conduct geodiversity studies, a conclusion that has also been reached by others working in this field (Zwoliński et al., 2018, p. 27). The criteria used by geologists in the main stream geodiversity studies differ from those used by the biodiversity and pedodiversity communities; the biodiversity and pedodiversity communities are utilizing similar criteria. The adoption of universal criteria is a prerequisite for the progress of any scientific discipline, and it seems that the adoption of universal criteria by the various communities studying natural resource diversity would be a major step forward in allowing the results of these different groups to be compared, contrasted, and utilized in the policy-making process.
As mentioned above, a fascinating exception in the geodiversity bibliography concerns mineral diversity. R.M. Hazen as well as G. Ausubel and coworkers used the universal classifications of mineral types and the Mindat database (which specifies its spatial distribution at the worldwide level) to carry out very interesting research with findings that are very similar to those detected in pedodiversity analysis (Hazen et al., 2015; Hazen and Ausubel, 2016; Hystad et al., 2015a, 2015b). These authors were able to predict the number of mineral species not yet described, their relative abundance, patterns of spatial distribution, the percentage of minerals that appeared due to the influence of life and proposed models of mineral evolution throughout the history of the earth. However, it is surprising that such studies have not aroused the interest of geodiversity experts from other disciplines involved.

\section{Conclusions}

As both a science as well as a scientific paradigm, studies of the diversity of a given natural resource began in the disciplines of ecology and conservation biology. After the Rio Summit, when the neologism biodiversity was popularized, the neologisms geodiversity and pedodiversity were proposed. However, studies of geodiversity and pedodiversity have been conducted by different communities of practitioners who followed different paths and there has been little communication between them. While pedologists followed the tradition of biodiversity experts with a view to understanding the structure and spatial distribution of soil landscapes, geologists focused primarily on geoconservation without addressing the literature already available in the fields of biodiversity and conservation of biological resources. The only exception detected is the recent research into mineral diversity that is similar in many ways to the approaches followed in biodiversity and pedodiversity studies.

Currently, the scientific community is focused on transdisciplinary studies that break boundaries with the goal of obtaining a more holistic view of natural resources. If this doctrine had been followed, surely studies in both geodiversity and pedodiversity would have progressed in more fruitful ways. It should not be forgotten that pedodiversity is 
one of the many elements that make up geodiversity. However, the first quantitative studies on pedodiversity were carried out and published before the Rio Summit.

The literature review showed that there is considerable geographic imbalance in the geodiversity studies that were conducted through the beginning of 2017. This imbalance threatens to hinder the development of geodiversity as an area of academic study, as it is important to consider diverse perspectives and viewpoints to achieve complete development of a field. There is also a strong geographic imbalance in the establishment of geoparks, which means global geodiversity is not adequately cataloged or protected. Future work should seek to correct this geographic imbalance, investigate whether the spatial patterns of biodiversity are idiosyncratic or are a characteristic of abiotic resources (lithology, landforms, soils, etc.), and standardize natural diversity research methods.

\section{References}

Beckett, P.H.T., Bie, S.W., 1978. Use of soil and land-system maps to provide soil information in Australia. Division of Soils Technical Paper vol. 33. Commonwealth Scientific and Industrial Research Organization, Australia.

Bétard, F., Peulvast, J.P., Magalhães, A.d.O., Neta, M.d.L.C., de Freitas, F.I., 2017. Araripe Basin: a major geodiversity hotspot in Brazil. Geoheritage https://doi.org/10.1007/ s12371-017-0232-5.

Birkeland, P.W., 1999. Soils and Geomorphology. 2nd edn. Oxford University Press, Oxford.

Brevik, E.C., Fenton, T.E., 1999. Improved mapping of the Lake Agassiz Herman strandline by integrating geological and soil maps. J. Paleolimnol. 22 (3), 253-257.

Brevik, E.C., Miller, B.A., 2015. The use of soil surveys to aid in geologic mapping with an emphasis on the eastern and midwestern United States. Soil Horiz. 56 (4). https://doi. org/10.2136/sh15-01-0001.

Brevik, E.C., Fenton, T.E., Homburg, J.A., 2016. Historical highlights in American soil science - prehistory to the 1970s. Catena 146, 111-127. https://doi.org/10.1016/j. catena.2015.10.003.

Bridges, E.M., 1990. World Geomorphology. Cambridge University Press, Cambridge USA.

Bunnell, F.L., 1998. Overcoming paralysis by complexity when establishing operationa goals for biodiversity. J. Sustain. For. 7 (3-4), 145-164.

Cerdà, A., Rodrigo-Comino, J., Giménez-Morera, A., Keesstra, S.D., 2018. Hydrological and erosional impact and farmer's perception on catch crops and weeds in citrus organic farming in Canyoles river watershed, Eastern Spain. Agric. Ecosyst. Environ. 258, 49-58.

Conway, J., 2010. A soil trail?-a case study from Anglesey, Wales, UK. Geoheritage 2 $15-24$.

Coratza, P., Giusti, C., 2005. Methodological proposal for the assessment of the scientific quality of geomorphosites. Quaternario 18 (1), 307-313.

De-Alba, S., Saldaña, A., Ibáñez, J.J., Zinck, A., Pérez-González, S., 1993. Repercusiones de la evolución de los sistemas de incisión fluvial sobre la complejidad de los paisajes geomorfológicos en áreas con superficies de tipo raña. In: Pinilla, A. (Ed.), La Raña en España y Portugal (Proceedings of the Simposium sobre la Raña en España y Portugal, Madrid, 25-30, 11, 1992), Abstracts in English. Monografías del CCMA, ${ }^{\circ}$ 2. CSIC, Madrid, pp. 81-93.

Eyre, S.R., 2013. Vegetation and Soils: A World Picture. 2nd edition. Aldine Transaction, London.

Gallart, F., Marignani, M., Pérez-Gallego, N., Santi, E., Maccherini, S., 2013. Thirty years of studies on badlands, from physical to vegetational approaches. A succinct review. Catena 106, 4-11. https://doi.org/10.1016/j.catena.2012.02.008.

Gerrard, J., 1992. Soil Geomorphology: An Integration of Pedology and Geomorphology. Springer, London.

Gray, M., 2004. Geodiversity - Valuing and Conserving Abiotic Nature. John Wiley \& Sons Ltd, Chichester (434 pp.)

Gray, M., 2008. Geodiversity: developing the paradigm. Proc. Geol. Assoc. 119, 287-298.

Harner, R.F., Harper, K.T., 1976. The role of area, heterogeneity, and favourability in plant species diversity of pinyon-juniper ecosystems. Ecology 57, 1254-1263.

Harper, D.A.T., Benton, M.J., 2001. Preface: history of biodiversity. Geol. J. 36, 185-186 https://doi.org/10.1002/gj.899.

Hazen, R.M., Ausubel, J.H., 2016. On the nature and significance of rarity in mineralogy. Am. Mineral. 101. https://doi.org/10.2138/am-2016-5601CCBY.

Hazen, R.M., Grew, E.S., Downs, R.T., Golden, J., Hystad, G., 2015. Mineral ecology: chance and necessity in the mineral diversity of terrestrial planets. Can. Mineral. 53 (2), 295-324. https://doi.org/10.3749/canmin.1400086.

Hjort, J., Gordon, J.E., Gray, M., Hunter, M.L., 2015. Why geodiversity matters in valuing nature's stage. Conserv. Biol. 29 (3), 630-639.

Howard, J.A., Mitchell, C.W., 1985. Phytogeomorphology. Wiley, New York.

Hupp, C.R., 1990. Vegetation patterns in relation to basin hydrogeomorphology. In: Thornes, J.B. (Ed.), Vegetation and Erosion: Processes and Environments. Wiley, Chichester, UK (217-237 pp.).

Huston, M.A.H., 1994. Biological Diversity. Cambridge Univ. Press, UK (681 pp.)

Huston, M.A., 1997. Hidden treatments in ecological experiments: re-evaluating the ecosystem function of biodiversity. Oceologia 110, 449-460.

Huxley, A., 1954. The Doors of Perception. Chatto and Windus, London.
Hystad, G., Downs, R.T., Grew, E.S., Hazen, R.M., 2015a. Statistical analysis of mineral diversity and distribution: Earth's mineralogy is unique. Earth Planet. Sci. Lett. 426 (2015), 154-157. https://doi.org/10.1016/j.epsl.2015.06.028.

Hystad, G., Downs, R.T., Hazen, R.M., 2015b. Mineral species frequency distribution conforms to a large number of rare events model: prediction of Earth's "missing" minerals. Math. Geosci. 47, 647-661. https://doi.org/10.1007/s11004-015-9600-3.

Ibáñez, J.J., 2014. Diversity of soils. Oxford Bibliographies. Geography. Oxford University Press https://doi.org/10.1093/OBO/9780199874002-0104 http://www. oxfordbibliographies.com/view/document/obo-9780199874002/obo9780199874002-0104.xml (article on line).

Ibáñez, J.J., Bockheim, J., 2013. Pedodiversity. CRC Press, Boca Raton, FL.

Ibáñez, J.J., Feoli, E.V., 2013. Global relationships of pedodiversity and biodiversity. Vadose Zone J. https://doi.org/10.2136/vzj2012.0186.

Ibáñez, J.J., Jiménez-Ballesta, R., García-Álvarez, A., 1990. Soil landscapes and drainage basins in Mediterranean mountain areas. Catena 17, 573-583. https://doi.org/10.1016/ 0341-8162(90)90031-8.

Ibáñez, J.J., Pérez-González, A., Jiménez-Ballesta, R., Saldaña, A., Gallardo-Díaz, J., 1994. Evolution of fluvial dissection landscapes in Mediterranean environments. Quantitative estimates and geomorphological, pedological and phytocenotic repercussions. Z. Geomorphol. N.F. 37, 123-138.

Ibáñez, J.J., De-Alba, S., Bermúdez, F.F., García-Álvarez, A., 1995. Pedodiversity: concepts and measures. Catena 24, 215-232. https://doi.org/10.1016/0341-8162(95)00028-0.

Ibáñez, J.J., Zuccarello, V., Ganis, P., Feoli, E., 2014. Pedodiversity deserves attention in plant biodiversity research. Plant Biosyst. 148 (6), 1-5. https://doi.org/10.1080/ 11263504.2014.980357.

Ibáñez, J.J., Pérez-Gómez, R., Brevik, E.C., Cerdà, A., 2016. Islands of biogeodiversity in arid lands on a polygons map study: detecting scale invariance patterns from natural resources maps. Sci. Total Environ. 573, 1638-1647. https://doi.org/10.1016/j. scitotenv.2016.09.172.

Jacobs Jr., D.R., Gross, M.D., Tapsell, L.C., 2009. Food synergy: an operational concept for understanding nutrition. Am. J. Clin. Nutr. 89 (5), 1543S-1548S.

Jobbagy, E.G., Jackson, R.B., 2000. The vertical distribution of soil organic carbon and its relation to climate and vegetation. Ecol. Appl. 10, 423-436.

Johnson, M.P., Simberloff, D.S., 1974. Environmental determinants of island species numbers in the British Isles. J. Biogeogr. 1, 149-154. https://doi.org/10.2307/3037964.

Karjalainen, P.T., 1983. Geodiversity: a humanistic interpretation. Terra 95, 221-226.

King, L.C., 1983. Wandering Continents and Spreading Sea Floors on an Expanding Earth. Wiley, Chichester UK

Kolay, A.-K., 2010. Soil Geology Hardcover. 2nd ed. Atlantic Publishers \& Distributors (P) Ltd., India.

Kruckeberg, A.R., 2002. Geology and Plant Life: The Effects of Landforms and Rock Types on Plants. University of Washington Press, Seattle.

Magurran, A.E., 2004. Measuring Biological Diversity. Blackwell, Oxford, UK 978-0-63205633-0.

Matthews, T.J., 2014. Integrating geoconservation and biodiversity conservation: theoretical foundations and conservation recommendations in a European Union context. Geoheritage 6, 57-70.

McBratney, A.B., 1992. On variation, uncertainty and informatics in environmental soil management. Aust. J. Soil Res. 30, 913-935.

Melelli, L., Vergari, F., Liucci, L., Del Monte, M., 2017. Geomorphodiversity index: quantifying the diversity of landforms and physical landscape. Sci. Total Environ. 584-585, 701-714.

MINDAT Database. https://www.mindat.org/, Accessed date: 23 August 2018.

Moreno-Sánchez, I., Font-Clos, F., Corral, A., 2016. Large-scale analysis of Zipf's law in English texts. PLoS One https://doi.org/10.1371/journal.pone.0147073.

Naeem, S., Loreau, M., Inchausti, P., 2002. Biodiversity and ecosystem functioning: the emergence of a synthetic ecological framework. In: Loreau, M., Naeem, S., Inchusti, P. (Eds.), Biodiversity and Ecosystem Functioning: Synthesis and Perspectives. Oxford University Press, Oxford, pp. 3-11.

Noss, R.F., 1990. Indicators for monitoring biodiversity: a hierarchical approach. Conserv. Biol. 4 (4), 355-364.

Ollier, C., Pain, C., 1996. Regolith, Soils, and Landforms. John Wiley, New York.

Panizza, M., 2009. The geomorphodiversity of the Dolomites (Italy): a key of geoheritage assessment. Geoheritage 1 (1), 33-42.

Parks, J.E., Mulligan, M., 2010. On the relationship between a resource based measure of geodiversity and broad scale biodiversity patterns. Biodivers. Conserv. 19, 2751-2766. https://doi.org/10.1007/s10531-010-9876-z.

Pemberton, M., 2007. A Brief Consideration of Geodiversity and Geoconservation. Department of Primary Industries and Water, Tasmania http://citeseerx.ist.psu.edu/ viewdoc/summary?doi $=10.1 .1 .554 .610$

Pereira, P., Mierauskas, P., Novara, A., 2016. Stakeholders' perceptions about fire impacts on Lithuanian protected areas. Land Degrad. Dev. 27 (4), 871-883. https://doi.org/ 10.1002/ldr.2290.

Phillips, C.P., 1998. The badlands of Italy: a vanishing landscape? Appl. Geogr. 18, 243-257. https://doi.org/10.1016/S0143-6228(98)00005-8.

Reynard, E., Fontana, G., Kozlik, L., Scapozza, C., 2007. A method for assessing "scientific" and "additional values" of geomorphosites. Geogr. Helv. 62, 148-158.

Rodrigo Comino, J., María Senciales, J., Cerdà, A., Brevik, E.C., 2018. The multidisciplinary origin of soil geography: a review. Earth Sci. Rev. 177, 114-123.

Sá dos Santos, W.F., de Souza Carvalho, I., Brilha, J.B., Leonardi, G., 2016. Inventory and assessment of palaeontological sites in the Sousa Basin (Paraíba, Brazil): preliminary study to evaluate the potential of the area to become a geopark. Geoheritage 8, 315-332.

Scheffer, M., 1999. Searching explanations of nature in the mirror world of math. Conserv. Ecol. 3 (2), 1-20. 
Schroeder, M.R., 1992. Fractals, Chaos, Power Laws: Minutes From an Infinite Paradise. Dover Books on Physics, Mineoly, NY.

Shannon, C.E., Weaver, W., 1949. The Mathematical Theory of Communication. University of Illinois Press, Urbana.

Sharples, C., 1993. A Methodology for the Identification of Significant Landforms and Geological Sites for Geoconservation Purposes. Forestry Commission, Tasmania.

Sites Jr., J.W., Marshall, J.C., 2004. Operational criteria for delimiting species. Annu. Rev. Ecol. Evol. Syst. 35, 199-227.

Soini, K., Vaarala, H., Pouta, E., 2012. Residents' sense of place and landscape perceptions at the rural-urban interface. Landsc. Urban Plan. 104 (1), 124-134.

Stallins, J.A., 2006. Geomorphology and ecology: unifying themes for complex systems in biogeomorphology. Geomorphology 77, 207-216.

Steward, J.H., 1986. Levels of sociocultural integration: an operational concept. J. Anthropol. Res. 42 (3), 337-353.

Tempesta, T., 2010. The perception of agrarian historical landscapes: a study of the Veneto plain in Italy. Landsc. Urban Plan. 97 (4), 258-272.

Teshome, A., de Graaff, J., Ritsema, C., Kassie, M., 2016. Farmers' perceptions about the influence of land quality, land fragmentation and tenure systems on sustainable land management in the north western Ethiopian highlands. Land Degrad. Dev. 27 (4), 884-898. https://doi.org/10.1002/ldr.2298.

Testa, B., Aldighieri, B., Bertini, A., Blendinger, W., Caielli, G., de Franco, R., Giordano, D. Kustatscher, E., 2013. Geomorphodiversity of the San Lucano Valley (Belluno Dolomites, Italy): a well-preserved heritage. Geoheritage 5, 151-172. https://doi.org/ 10.1007/s12371-013-0079-3.
Triantis, K.A., Mylonas, M., Lika, K., Vardinoyannis, K., 2003. A model for the species-areahabitat relationship. J. Biogeogr. 30, 19-27. https://doi.org/10.1046/j.13652699.2003.00805.x.

UN, 2018. Member States. http://www.un.org/en/member-states/, Accessed date: 25 February 2018.

UNESCO, 2017. Where are the UNESCO Global Geoparks? http://www.unesco.org/new/ en/natural-sciences/environment/earth-sciences/unesco-global-geoparks/frequently-asked-questions/where-are-the-unesco-global-geoparks/, Accessed date: 22 February 2018

US Dept. of State, 2017. Independent States in the World. https://www.state.gov/s/inr/rls/ 4250.htm.

Valls, A., Coll, M., Christensen, V., 2015. Keystone species: toward an operational concept for marine biodiversity conservation. Ecol. Monogr. 85 (1), 29-47.

Williamson, M.H., 1981. Island Populations. Oxford University Press, Oxford.

Zinck, A., Metternicht, G., Bocco, G., del Valle, H. (Eds.), 2016. Geopedology: SoilLandscape Relationships. Springer, Heilderberg https://doi.org/10.1007/978-3-31919159-1.

Zink, J.A., 2013. Geopedology. Elements of Geomorphology for Soil and Geohazard Studies. ITC, Enschede, The Netherlands 978-90-6164-352-4.

Zwoliński, Z., Najwer, A., Giardino, M., 2018. Methods for assessing geodiversity. In: Reynard, E., Brilha, J. (Eds.), Geoheritage: Assessment, Protection, and Management Elsevier, Amsterdam, pp. 27-52. 